\title{
Bacteriological Study of Vegetables from Markets of Osun State South Nigeria
}

\author{
${ }^{1}$ Alaje D.O and ${ }^{2}$ Owolabi K.T \\ ${ }^{1}$ Department of Applied Sciences, Osun State Polytechnic, Iree, Nigeria. \\ ${ }^{2}$ Department of Science Laboratory, Osun State Polytechnic, Iree, Nigeria.
}

\begin{abstract}
Three vegetables, lycopersicon esculentu (tomato), Telfaria occidentialis (Pumpkin leaves) Allium cepa (onion) were purchased from various markets in Osogbo metropolis and studied to determine their level of contamination and safety for human consumption. All the vegetables were washed with distil water, cultured with blood agar and subculture in nutrient agar to obtain pure cultures. 153 bacteria isolates made up of seven species of bacteria were made from the three vegetable groups. Bacillus species 70(45.16\%) Microcaus spp .6 (3.87\%), Escherichia coli 46(27.74\%), Proteus vulgaris 6(3.87\%), lactobacillus acidophilus 8(5.16\%). Enterobacter aerogeres 12(29.68\%), Alcaligen faecalis $7(4.52 \%)$ were the bacteria species were isolated bacillus, E.coli, were isolated from all the vegetables. All the seven bacteria species that isolated from tomatoes and fluted pumpkin leaves. Bacillus isolates were significantly higher than other bacteria isolates $(P<0.5)$, variable bacteria counts from the vegetables were highest in tomatoes $9.3 \times 10^{7} \mathrm{cfu} 1 \mathrm{ml}$; vegetable contamination with bacteria was observed in all the market highest in Alamisi market and least in Igbona market but statistically not significant $(P>0.05)$. Poor processing by retailers and handling by sellers with unwashed hands was the attributed sources of vegetable contamination with bacteria. Row vegetable from the markets were considered unfit for human consumption and adequate cooking with proper handling before consumption is suggested.
\end{abstract}

\section{Introduction}

Vegetables are those plants which are consumed in relatively small quantities as a side dish with stable food. In order to keep them from losing their full turgidity, harvested vegetables often requires low temperature and moist environment during storage. As a result, vegetable in the form of leaves are often sprinkled with water after harvesting and during exposure in the open market. The moist condition of the vegetables fostered by the sprinkling of water together with low temperature condition encourages the growth of microorganisms. These conditions also facilitate direct contamination by microorganisms through the handlers (buyers and sellers). In direct contamination may also occur as a result of poor hygienic environment of the market. Consequently, harvested vegetables so soon begin to spoil if not sold immediately. However, cleaning process reduce the number of microorganism. Fluted pumpkin or Ugu is know scientifically as Telfairia occidentalis, a tropical vine plant native to West Africa but occurs mostly in its cultivated firm in various part of southern Nigeria. The seed are also nutrition's and rich in oil which may be used for cooking soup manufactures it has long bean discovered that when its essential ingredients are not destroyed it has the capacity to increase the red blood cell within a short time after consumption. Any fruit of the numerous cultivated varieties of lycopersicon esculentu, a plant of the night sade family (solanaceae), also, the fruit of L. pimpineli folium the thing current tomatoes. Tomatoes plants are generally much branched, spreading 60-180 cm (24-72inches) and recumbert when fruiting, but a few forms are compact and upright. Leaves are more or less hairy, strongly odorous, pinnately compound and grow up to $45 \mathrm{~cm}$ long. Tomatoes were introduced to North America from Europe, Thomas Jefferson is known to have raised them at monticells in 1781. the tomatoes was used for food in Lovisiana as early as 1812, but not in the northern eastern states until about 1835, and it did not attain widespread popularity in the United States until the early $20^{\text {th }}$ century. Onion (allium cepa), which is also known as the bulb onion, common onion ${ }^{2}$ is the most widely cultivated species of the genus allium ${ }^{3}$. onion is most frequently a biennial although it can also be a triennial or a perennial. Allium cepa is know exclusively in exclusively in cultivation, but related wild species occur in central Asia ${ }^{5}$. The most closely related species include allium vavilovii (popov \& vied) and allium as are use (R.mfritsch \& matin) from Iran ${ }^{7}$. The onion is easily propagated, transported and stored. The ancient Egyptians worshiped it ${ }^{8}$, believing its spherical shape and concentric rings symbolize eternal life. Onion were even used in Egyptian burial, as evidenced by onion traces being found in the eye sockets of Ramesses IV. In the middle ages, onions were such an important food that people would pay their rent with onions and even give them as gift ${ }^{9}$ Doctor were known to prescribe onion to facilitate bowel movements and erections, and also to relieve headaches, coughs, snakebite and hair loss and in the early $16^{\text {th }}$ century to help with infertility in women, and even dogs, cats and cattle many other household pets ${ }^{10}$. Native American Indian used wild onions 
in variety of ways eating them raw or cooked, as a seasoning or as a vegetable. Such onions were also used in syrups, as poultices, as an ingredient in dyes and even as toys.

\section{Materials and Methods}

The vegetable samples numbering fifteen (three samples from each market were bought, from (3) three different markets namely: Thursday Igbona, and Ada market in Osun metropolis. Osun is located in the world map on coordinates the southern part of Nigeria with an estimated population of 1million people southern Nigeria has a tropical continental climate with district wet and dry season.

\section{Handling And Washing Of The Vegetables}

Sterile polythene bags were used to collect and transport the purchased samples to the laboratory. A pair of forceps was flamed, allowed to cool, used to pick the samples and transferred into sterile contains. Sterile distilled water was poured into these containers washing was done by shaking and rocking of the containers.

\section{Method Of Cutting The Washing From The Vegetables.}

Serial dilution of the washings was done in which $1 \mathrm{ml}$ of each washing was added into a test tube containing $9 \mathrm{ml}$ of sterile distilled water. Serial tenfold dilution was carried out from $10^{-1}$ to $10^{-10}$. This was followed by pour plate technique. One million aliquot of each dilution from $10^{-2}, 10^{-5}$ and $10^{-7}$ were cultured into blood agar, MacConkey agar and Nutrient agar plates respectively. The lid was replaced in each case. Rocking of these plates were done as soon as the agar were poured, so as to have the microorganisms evenly separated during growth. Solidification of these agars was followed by incubation at $37^{\circ} \mathrm{C}$ for 24 hours. After 24 hours colonies were observed, counted and recorded.

\section{Sub Culturing}

The colonies were purified by sub culturing then in fresh nutrient agar plates. After purification, the isolate were maintained using nutrient agar slant and were kept in the refrigerator at $4^{0} \mathrm{C}$ for identification.

\section{Identification Of Various Isolates Obtained In The Cultures.}

The following biochemical tests were carried out for the characterization and identification of the organisms, viz; Grains stain, catalase test, indole test, oxidase test, sugar fermentation test, motility test, coaqulase test, citrate utilization test, hydrogen sulphide production test, voges-proskquer test, methyl red test and haemolytic reaction on blood agar.

\section{Estimation Of Intensity Of Contamination}

Intensity of contamination was estimated by using the viable count technique. Only plates that showed not less than 30colonies and not more than 300 colonies were used for this estimation. Colony forming unit (CFU) was used as the standard unit for the estimation and is defined by;

$\mathrm{CFU}=$ Average colony count $\mathrm{x}$ dilution factor $\mathrm{x}$ volume used.

Table 1: Bacteria isolates from Thursday market samples from the vegetable sample

\begin{tabular}{l|c|c}
\hline \multicolumn{1}{c|}{ Isolates } & Number of isolates & Percentages incidence (\%) \\
\hline Bacillus spp. & 27 & 50.94 \\
Micrococcus spp. & 1 & 01.89 \\
Escherichia coli & 14 & 26.42 \\
Proteus vulgaris & 2 & 03.77 \\
Enterobacter aerogenes & 5 & 09.43 \\
Lactobacillus acidophilus & 2 & 03.77 \\
Alcaligen faecalis & 2 & 03.77 \\
\hline Total & $\mathbf{5 3}$ & $\mathbf{1 0 0 . 0 0}$ \\
\hline
\end{tabular}

Table 2: Bacteria Isolates from Igbona market samples

\begin{tabular}{l|c|c}
\multicolumn{1}{c|}{ Isolates } & Number Of Isolates & Percentages Incidence (\%) \\
\hline Bacillus Spp. & 20 & 38.46 \\
Micrococcus Spp. & 2 & 3.85 \\
Escherichia Coli & 20 & 38.46 \\
Proteus Vulgaris & 4 & 7.69 \\
Enterobacter Aerogenes & 3 & 5.77 \\
Lactobacillus Acidophilus & 2 & 3.85 \\
Alcaligen Faecalis & 1 & 1.92 \\
\hline Total & $\mathbf{5 2}$ & $\mathbf{1 0 0 . 0 0}$ \\
\hline
\end{tabular}


Table 3: Bacteria isolates from Ada market samples from 3 vegetables

\begin{tabular}{c|c|c}
\hline Isolates & Number Of Isolates & Percentages Incidence (\%) \\
\hline Bacillus Spp. & 23 & 66 \\
Micrococcus Spp. & 3 & 24 \\
Escherichia Coli & 12 & 2 \\
Proteus Vulgaris & 1 & 6 \\
Enterobacter Aerogenes & 3 & 8 \\
Lactobacillus Acidophilus & 4 & 8 \\
\hline Alcaligen Faecalis & 4 & $\mathbf{1 0 0 . 0 0}$ \\
\hline
\end{tabular}

Table 4: Comparison of Bacteria isolates from the markets in Osun metropolis number of isolates from the three market.

\begin{tabular}{l|c|c|c|c|c}
\hline \multicolumn{1}{c|}{ Isolates } & \% & Thursday & Igbona & Ada & Total \\
\hline Bacillus spp. & 45.16 & 27 & 20 & 23 & 70 \\
Micrococcus spp. & 3.87 & 1 & 2 & 3 & 6 \\
Escherichia coli & 29.68 & 14 & 20 & 12 & 46 \\
Proteus vulgaris & 7.87 & 2 & 3 & 6 & 1 \\
Enterobacter aerogeres & 5.16 & 2 & 2 & 3 & 4 \\
Lactobacillus acidophilus & 4.52 & 2 & 1 & 4 & 7 \\
Akaligen faccolis & & $\mathbf{5 3 ( 3 4 . 1 9 )}$ & $\mathbf{5 2 ( 3 3 . 5 5 )}$ & $\mathbf{5 0 ( 3 2 . 2 6 )}$ & $\mathbf{1 5 5}(\mathbf{1 0 0})$ \\
\hline Total & & & &
\end{tabular}

Number and percentage (\%) distribution on the vegetables

Table 5: Distribution of individual bacterial isolates on the vegetables

\begin{tabular}{|c|c|c|c|c|}
\hline Bacteria species & Total no of isolates & Tomatoes & Pumpkin leaves & Onions \\
\hline Bacillus spp & 70 & $\begin{array}{c}30 \\
(42.86)\end{array}$ & $\begin{array}{c}25 \\
(35.71)\end{array}$ & $\begin{array}{c}15 \\
(21.43)\end{array}$ \\
\hline Micrococcus spp & 6 & $\begin{array}{c}3 \\
(50.00)\end{array}$ & $\begin{array}{c}1 \\
(16.67)\end{array}$ & $\begin{array}{c}2 \\
(33.33)\end{array}$ \\
\hline Escherichia coli & 46 & $\begin{array}{c}15 \\
(32.61)\end{array}$ & $\begin{array}{c}12 \\
(26.09)\end{array}$ & $\begin{array}{c}19 \\
(41.30)\end{array}$ \\
\hline Proteins vulgaris & 6 & $\begin{array}{c}2 \\
(33.33)\end{array}$ & $\begin{array}{c}3 \\
(50.00)\end{array}$ & $\begin{array}{c}1 \\
(16.67)\end{array}$ \\
\hline Enterobacter aerogenes & 12 & $\begin{array}{c}6 \\
(50.00)\end{array}$ & $\begin{array}{c}4 \\
(33.33)\end{array}$ & $\begin{array}{c}2 \\
(16.67)\end{array}$ \\
\hline Lactobaccilus acidophilus & 8 & $\begin{array}{c}4 \\
(50.00)\end{array}$ & $\begin{array}{c}3 \\
(37.50)\end{array}$ & $\begin{array}{c}1 \\
(12.50)\end{array}$ \\
\hline Akaligin faecolis & 7 & $\begin{array}{c}3 \\
(42.86)\end{array}$ & $\begin{array}{c}4 \\
(57.14)\end{array}$ & $\begin{array}{c}\mathrm{Nil} \\
()\end{array}$ \\
\hline
\end{tabular}



Figure 1: Percentage frequency distribution of the bacteria isolates on the vegetables. 


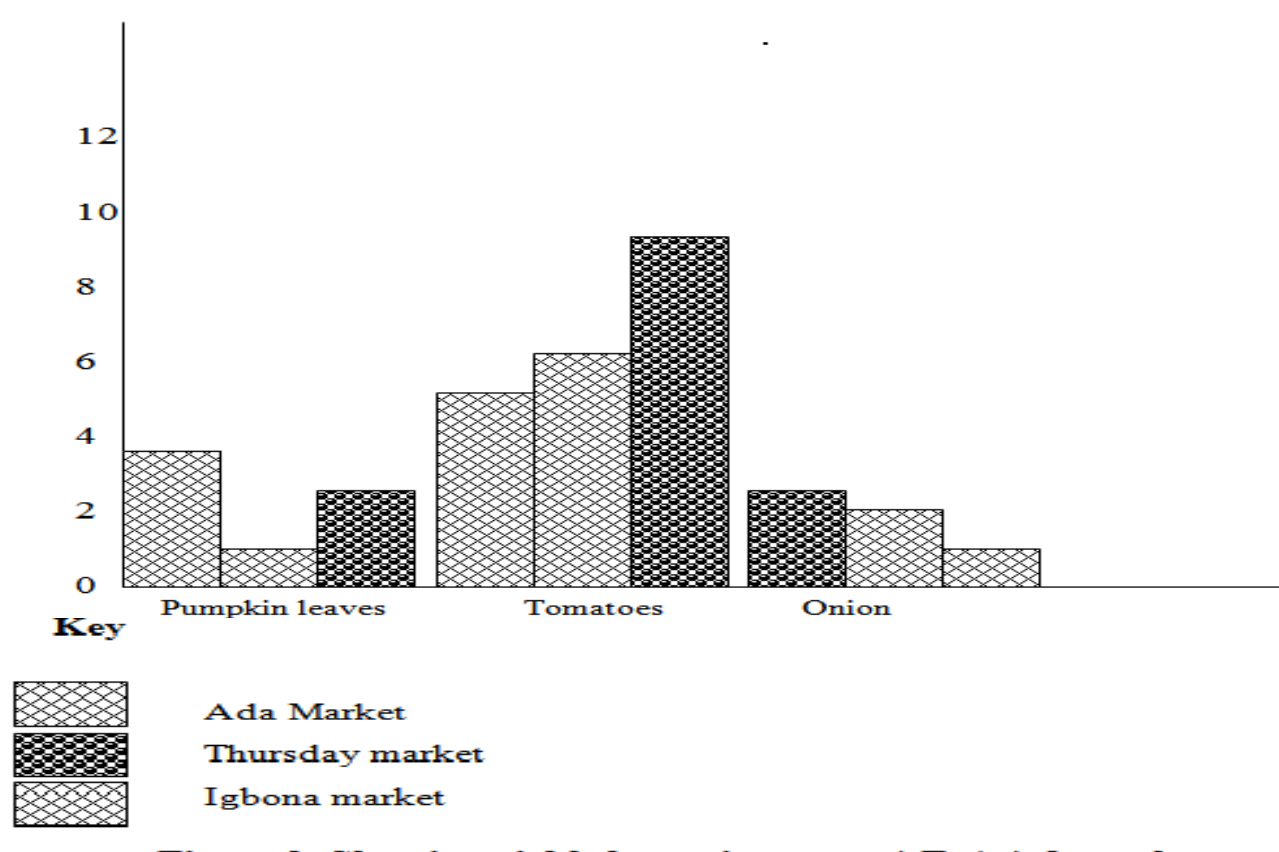

Figure 2: Showing viable bacteria counts (cFu/m) from the vegetables

\section{Results}

The bacterial isolates from the vegetables in Thursday market are shown in table 1. altogether 53 bacteria isolates were made. Bacillus spp had the highest incidence 27 (50.94\%) followed by Escherichia coli 14 (26.42\%), Enterobacter aerogenes 5(9.43\%) while each of Lactobaccilus acidophilus and Alcaligen faecalis had an incidence of $2(3.77 \%)$ and Micrococcus spp recorded the lowest incidence of 1(1.89\%).

The bacteria isolates from the vegetables samples from Igbona market are shown in table 2. Altogether 52 isolates were made. Again Bacillus spp and Escherichia coli had the highest incidence 20(38.46\%) followed by enterobacteria aerogenes 4(7.69\%), Proteus vulgaris 3(5.77\%), while acidophillus and Micrococcus spp had an incidence of $2(3.85 \%)$ each and Alcaligan faecalis had the lowest incidence of $1(1.92 \%)$.

From the Ada market, 50 bacteria isolates were made (table 3). Bacillus sp had the highest incidence of 23 (46\%), followed by Escherichia coli 12 (24\%), while Lactobacillus acidophilus and Alcaligen faecalis had an incidence of $4(8 \%)$ each and Micrococcus spp and enterobacteria also had an incidence of $3(6 \%)$ each, meanwhile, Proteus vulgaris had the lowest incidence of $1(2 \%)$.

Table 4 shows a comparison of the bacteria isolates from the three markets of Osogbo metropolis. From total of 155 bacteria isolates made from the three markets, 53 (34.19\%) were from Thursday markets, 52(33.55\%) were from Igbona market while 50(32.26) were Ada market. Although the isolates from Thursday and Igbona markets were slightly higher than that of Ada market, they were not significantly higher $(\mathrm{P}>0.05)$ than that of the Ada market.

Seven bacteria species namely Bacillus spp, Micrococcus spp, Escherichia coli, Proteus vulgaris, Enterobacteria aerogenes, Lactobacillus acidophilus and Alcaligen faecalis, from the three markets, Bacillus species isolates $70(45.16 \%)$ were significantly higher $(\mathrm{P}<0.05)$ than other bacteria isolates. In the order of their significance Bacillus was followed by Escherichia coli 46 (29.68\%) and Enterobacter aerogenes 12(7.74\%). Others were lactobacillus acidophilus 8(5.16\%), Alcaligen faecalis 7(4.52\%), Proteus vulgaris and micrococcus species had an incidence of $6(3.87 \%)$ each.

The distribution of individual bacteria isolates on the vegetables is shown in table 5 of the seven bacteria species, Bacillus species and Escherichia coli were isolated from all the three vegetable groups studied. The highest number of bacillus isolates 30(42.86\%) were from tomatoes while the least 15(21.43\%) were from onion. Also the highest number of Escherichia coli isolates 19(41.30\%) were from onion and least 12 (26.09\%) were from pumpkin leaves. Micrococcus spp. isolates highest in tomatoes 3(50\%) and lowest $1(16.67 \%)$ were from pumpkin leaves, Proteus vulgaris were isolated had highest of 3(50\%) from while the least isolated 1(16.67\%) were from onion. The highest number of Enterobacter aerogenes isolates 6(50\%) were from tomatoes and the least 2(16.67) from onion. Also the highest number of Lactobacillus isolates $4(50 \%)$ were from tomatoes and least number 1(12.50) were from onion. Moreover, Alcaligen faecalis isolates highest number $4(57.14 \%)$ and least number 3(42.86\%) while Alcaligen faecalis were not isolated from onion. Five bacteria species namely Bacillus spp., E.coli, E. aerogenes, L. acidophilus and A. alcaligens had their highest isolates from tomatoes and fluted pumpkin leaves (one isolate from each). All the seven bacteria isolates were 
made from tomatoes and fluted pumpkin leaves. Onion has all the seven bacteria isolates with the exception of Alcaligen faecalis.

The percentage distribution of the isolates on the vegetables is represented in figure 1.155 bacteria isolates $63(40.65 \%)$ were from tomatoes, 52(33.55) from fluted pumpkin leaves and $40(25.80 \%)$ from onion.

The viable bacteria counts from the different vegetable bought from markets of Osogbo metropolis were shown in figure 2 . Tomatoes (Lycopersicon esculent) recorded very high bacteria counts in all the three markets in Osogbo metropolis with $4.5 \times 10^{7} \mathrm{cfu} / \mathrm{ml}, 5.5 \times 10^{7} \mathrm{cfu} / \mathrm{ml}$, and $8.8 \times 10^{7} \mathrm{cfu} / \mathrm{ml}$ respectively in Ada, Igbona and Thursday market. Fluted pumpkin leaves recorded its highest count of $3.9 \times 10^{7} \mathrm{cfu} / \mathrm{ml}$ in Igbona market. Allium cepa (onion) recorded its highest bacteria count $3.0 \times 10^{7} \mathrm{cfu} / \mathrm{ml}$ in Thursday market.

\section{Discussion}

In Osogbo metropolies markets, the commonly sold vegetables such as Lycopersicon esculentu, Telfania occidentalis and Allium cepa were found to be contaminated with bacteria. This contamination could be as a result of poor processing methods which may involve washing with faecal contaminated stream water and spraying the vegetable with water. Though spraying with water gives fresh appearance to the vegetables and delays decomposition but it could add microorganisms, especially, psychrotrophs from water or ice. This spray method provides moist surface that encourages bacteria growth on longer storage. Also vegetables are subject to contamination by containers unless adequately sanitized.

The bacteria isolates from the vegetables samples were Bacillus species, Micrococcus species, Escherichia coli, Proteus vulgaris, Enterobacter aerogenes, Lactobacillus acidophilus and Alcaligen faecalis. The distribution of these isolates varied with different vegetables. Bacillus species was found to have high count in (tomatoes) Lycopersicum esculentu while low count was recorded in Allium cepa (onion).

The low bacteria count Allium cepa may be due to anti-microbial compounds in them which are inhibitory to multiplication of microorganisms. Distribution of bacteria isolates also differed in the different markets. Thursday market recorded the highest bacteria in Bacillus species while Igbona market recorded the least count in this isolate. But Thursday and Igbona markets yielded very low count for Micrococcus species.

The higher incidences of Bacillus species over others may be due to its spores which could resist killing by high temperature of ultra-violet sun rays which may kill and reduce the bacteria head in vegetables during exposure and display for sale High incidence of Escherichia coli may probably be due to handling by buyers and sellers whose hands may have been contaminated with faecal matters or they may have been contaminated from the farm yards when fertilized with human or animal manures. Bacillus spp has been implicated as one of the common contaminates of vegetables. The presence of Enterobacter aerogenes and Alcaligen faecalis could probably be due to washing of these vegetables with water contaminated with faecal matter. Low incidences of Lactobacillus acidophilus may be attributed to their inability to produce spores like Bacillus species. Being acidophilic, their survival and multiplication require acidic and relatively anaerobic conditions, which are not provided for on these vegetables.

All the bacteria isolated were opportunistic pathogens, in that; they usually cause infection if suitable opportunity arises. This suitable opportunity could be seen in a person with weak natural immunity probably due to poor health, malnutrition, infection HIV or drug therapy.

\section{Conclusion}

Conclusively, adequate care should be taken in processing these vegetables to destroy the microorganisms before they enter inside the human body and obtain favourable conditions which could be support their increase in number; thereby causing food-borne disease or food poisoning to the detriment of the human health.

\section{References}

[1]. Banwart, G.J (2001). Bacteria as food organisms. Basic food microbiology. Avi publishing Co-West port conn. Pp 119-125.

[2]. Bessie E., Breadley, H and Sundberg C (2007). Keeping food safe Doubleday and company Inc.Garden city New York.

[3]. Brewster, James L. (1994). Onions and other vegetables aluminum ( ${ }^{\text {st }}$ Ed). Waltinford, Uk: CAB International p 16 ISBN 0-85798753-2

[4]. Canadian produce Marketing Association Home storage Guide for Fresh fruits and vegetables. Retrieved August 2010.

[5]. Germplasm Resources Information Network (GRIN). "Allium cepa information from NPGS/GRIN. USDA, ARS, National Genetic Resources Program. Retrieved 22 April 2011.

[6]. Frazier W.C and Westhoff. D.C (2005). Food Microbiology. McGraw-Hill publishing company Ltd, New Delhi Pp 217-240.

[7]. Major Food and Agricultural commodities and Producers - Countries By commodity. FAO. Org. Retrieved 2012-05-18.

[8]. Peirce, L.C (2005): Vegetables: Characteristics, Production and Marketing. John Wiley, New York Pp. 55-90.

[9]. Rice, R.P., Rice L.W., and Tyndall, H.D (2002): Fruit and Vegetables production in Africa ( $2^{\text {nd }}$ edition). Macmillan Press Ltd, Hongkong, Pp. 8-12.

[10]. Schwab, A.H, Duran A.P., Barnard, R.J and Read, R.B (2008). Microbial quality of some spices and herbs in retail markets. Journal Applied and Environmental Microbiology 24(3): 627-630.

[11]. Tindall, H.D (2002): Vegetables in the tropics Liverpool University Pres, Hongkong Pp21. 